\title{
Postoperative Complications in Children with Congenital Neck Masses: A Review Article
}

\section{Volkan Sarper Erikci}

Sağlık Bilimleri University, Department of Pediatric Surgery, Tepecik Training Hospital, Izmir, Turkey

*Corresponding author: Volkan Sarper Erikci, Sağlık Bilimleri University, Department of Pediatric Surgery, Tepecik Training Hospital, Izmir, Turkey

Received date: March 03, 2020; Accepted date: March 13, 2020; published date: March 18, 2020

Citation: Volkan Sarper Erikci, Prognostic Factors and Survival of the Differentiated Thyroid Cancer Retrospective Study. J Clinical Research and Reports, 4(1); DOI:10.31579/2690-1919/063

Copyright: @ 2020 Volkan Sarper Erikci. This is an open access article distributed under the Creative Commons Attribution License, which permits unrestricted use, distribution, and reproduction in any medium, provided the original work is properly cited.

\section{Abstract}

Congenital neck lesions (CNL) are commonly seen in children. Due to different presentations and complications after surgical treatment, a thorough knowledge of regional anatomy is paramount in the management of these children. In this study it is aimed to review the frequently encountered surgical complications during and following surgical treatment of children with special reference to thyroglossal duct remnants, branchial cleft anomalies and dermoid cysts.

Key Words: thyroglossal duct remnants; branchial cleft anomalies; dermoid cysts; complication

\section{Introduction}

Congenital neck lesions (CNL) are common clinical concern in infants and children. The differential diagnosis includes congenital, inflammatory and neoplastic lesions. The physicians caring for children with CNLs should be aware of different presentations since these lesions are known to be complicated by infection. An orderly examination of the neck with a clear understanding of embryology and anatomy of the region will facilitate the diagnosis. The awareness of regional anatomy is important in avoiding injury to crucial structures during surgical intervention. In this study it is aimed to review the frequently encountered surgical conditions following surgery of children with CNL.

There are many reasons for CNL encountered in pediatric daily practice and most of these lesions include thyroglossal duct remnants (TGDR), branchial cleft anomalies (BCA) and dermoid cysts (DC) (1). TGDRs are the most common form of CNLs, accounting for up to $70-90 \%$ of such lesions (2-4). Main presentations of TGDR are that of a midline neck mass or infection as a single or a recurrent event. In a recent report, more than half of the patients (53.4\%) with CNLs presented with TGDR (5). A 7\% incidence of TGDR in a postmortem study of 200 adults has been reported (6). These lesions are commonly observed in children or adolescents and in a meta-analysis its incidence was found to be higher in children than in adults (7). Although there are conflicting reports with regard to sex distribution (8-10), equal distribution among males and females has been reported in most of the reviews $(7,11,12)$. It should be kept in mind that a true female dominance does exist amongst familial TGDRs (13). Diagnostic methods in the preoperative evaluation of TGDR include US, CT, MRI, radioisotope thyroid scanning, and thyroid function test (14). US is the most common test ordered in children and it is noninvasive and offers valuable information of both the TGDR and thyroid gland $(15,16)$. The absence of a normal appearing thyroid gland in the lower neck should alert the clinician that ectopic thyroid tissue might be present within the TGDR or elsewhere along the course of the thyroglossal duct and thyroid scintigraphy with thyroid function tests should be performed (17). Thoracic CT or MRI may be performed for the documentation of other comorbidities. Concerning fine needle aspiration, although the diagnostic sensitivity of $62 \%$ and a positive predictive value of $69 \%$ is reported, it is not popular for diagnosing TGDR in children $(14,18)$. The most common location for the cystic mass in TGDR is close proximity to the hyoid bone with an incidence of $66 \%$, but other locations including lingual, suprahyoid, suprasternal or within the thyroid gland have also been reported $(7,19)$.

The incidence of complications following the Sistrunk's procedure has been noted up to $29 \%$ (20). Recurrence is the most commonly seen complication following the surgical procedure for TGDR and it is reported to be $2.6 \%$ to $5 \%$ in most recent literature $(21,22)$. Deeper and wider excisions including removal of midportion of hyoid bone are suggested to remove any missed epithelial remnants during the subsequent operations in these patients. Apart from recurrence, abscess or hematoma requiring surgical drainage, inadvertent entry into the airway, tracheotomy, hypoglossal nerve paralysis, hypothyroidism have also been reported $(23,24)$. Intraoperative identification of the thyroid cartilage and thyrohyoid membrane is helpful landmark in identifying hyoid bone. Malignancy is often an underestimated complication which is reported fewer than $1 \%$ of patients with TGDR (25). Minor complications may include seroma, local wound infection and dehiscence (20). Although the Sistrunk's procedure is safe and successful technique with low complication rates, rare and life threatening complications should be kept in mind during the management of these children.

BCAs comprise $20 \%-30 \%$ of all head and neck lesions with an equal sex distribution (21,26-29). The most common type is the second cleft anomalies accounting for $95 \%$ of all lesions $(1,5)$. They present as cysts, sinuses, or fistulae and clinical presentation heavily depends on the type of the lesion and branchial fistulae and sinuses are diseases of childhood while cysts are more common in adults (30). However in the largest review of BCAs comprising 232 procedures, $90 \%$ of which included second branchial anomalies with an incidence of $13.5 \%$, only 28 children with second branchial anomalies demonstrated complete fistulae (31). An upper airway endoscopy may be useful in determining the presence of a pharyngeal opening (21). On the contrary to adults, fine needle aspiration biopsy or incisional biopsy should not be performed in children (26). US 
and CT may be helpful in defining the lesion, its anatomic course and for complete visualization of the tract (26). The definitive treatment of these lesions is complete surgical excision of the entire tract $(1,32)$. There is controversy on the timing of the resection. Some suggest early resection in order to prevent infection whereas others advocate waiting until the ages of 2-3 years $(26,33,34)$.

Recurrence is the most common complication following surgery for BCA and it has been reported as high as $22 \%$ (35). So during treatment of these lesions meticulous surgical technique should be performed. İnjury to nearby structures including internal jugular vein, carotid vessels, hypoglossal, glossopharyngeal nerves, mandibular branch of the fascial nerve should be kept in mind (36). In the case of bilateal fistula, an underlying genetic disorder including branchio-oto-renal syndrome should be considered (37). Other complications of BCA include lateral neck mass and suppurative thyroiditis which should raise the suspicion of a third BCA. Fascial plane disruption and scarring are other complications especially seen after surgery for third BCA and postoperative wound infection and transient horseness have also been reported following surgery for third BCA with the rates of $11 \%$ and 5.6\%, respectively (38)

Dermoid cyst is another lesion in the differential diagnosis of CNL. It is a germ cell tumor that results from the inclusion of embryonic epithelial elements, and contains ectodermal and endodermal components $(21,37)$. Nomenclature of these lesions is quite confusing and not uniform which are divided into epidermoid, dermoid and teratoid cysts based on the histological findings, the term DC has been used for all three lesions (39). Cervical lesions typically present $20 \%$ of head and neck dermoids and are usually diagnosed before the age of 3 years (21). Simple excision is all that is needed for cure but midline dermoids may travel through deeper tissues and may require a more extensive surgery (40). Recurrence is not usual occurrence but every effort should be made to remove the entire cyts without rupture of the cyst wall and spillage of contents (41). Intracranial extension is another rare complication which requires extensive surgery (40). Periosteal attachment may necessitate removal of bone fragement together with DC and should be kept in mind if the mass is not mobile on palpation.

\section{Conclusion}

In conclusion, complications following surgery for CNMs may be observed during the management of these children. Meticulous surgical resection is optimal choice of therapy not only for aesthetic reasons but for the avoidance of complications including recurrence. Early referral of these patients for pediatric surgeons and accurate and timely surgical treatment is suggested.

\section{References}

1. LaRiviere CA, Waldhausen JHT. Congenital cervical cysts, sinuses, and fistulae in Pediatric Surgery. Surg Clin North Am 2012; 92(3): 583-597.

2. Shah R, Gow K, Sobol SE. Outcome of thyroglossal duct cyst excision is independent of presenting age or symptomatology. Int J Pediatr Otorhinolaryngol 2007; 71(11): 1731-5.

3. Thomas JR . Thyroglossal-duct cysts. Ear Nose Throat J 1979; 58(12): 510-514.

4. Pounds LA. Neck masses of congenital origin. Pediatr Clin North Am 1981; 28(4): 841-844.

5. Erikci V, Hoşgör M. Management of congenital neck lesions in children. J Plast Reconstr Aesthet Surg 2014; 67(9): e217-e222.

6. Ellis PD, van Nostrand AW. The applied anatomy of thyroglossal duct remnants. Laryngoscope 1977; 87(5 Pt 1): 765-770.
7. Allard RH. The thyroglossal cyst. Head Neck Surg 1982; 5(2): 134-146.

8. Hsieh YY, Hsueh S, Lin JN. Pathologic analysis of congenital cervical cysts in children: 20 years of experience at Chang Gung Memorial Hospital. Chang Gung Med J 22003; 6(2): 107-113.

9. Al-Khateeb $\mathrm{TH}, \mathrm{Al}$ Zaubi F. Congenital neck masses: a descriptive retrospective study of 252 cases. J Oral Maxillofac Surg 2007; 65(11): 2242- 2247.

10. Türky1lmaz Z, Sönmez K, Karabulut R. Management of thyroglossal duct cysts in children. Pediatr Int 2004; 46(1): 7780 .

11. Brousseau VJ, Solares CA, Xu M. Thyroglossal duct cysts: presentation and management in children versus adults. Int $\mathrm{J}$ Pediatr Otorhinolaryngol 2003; 67(12): 1285-1290.

12. Lin ST, Tseng FY, Hsu CJ. Thyroglossal duct cyst: a comparison between children and adults. Am J Otolaryngol 2008; 29(2): 83-87.

13. Greinwald JH, Leichtman LG, Simko EJ. Hereditary thyroglossal cysts. Arch Otolaryngol Head Neck Surg 1996; 122(10): 1094-1096.

14. Ren W, Zhi K, Zhao L. Presentations and management of thyroglossal duct cyst in children versus adults: a review of 106 cases. Oral Surg Oral Med Oral Pathol Oral Radiol Endod 2011; 111(2): e1-e6.

15. Brewis $\mathrm{C}$, Mahadevan M, Bailey CM. Investigation and treatment of thyroglossal cysts in children. J R Soc Med 2000; 93(1): 18-21.

16. Ahuja AT, Wong KT, King AD. Imaging for thyroglossal duct cyst: the bare essentials. Clin Radiol 2005; 60(2): 141-148.

17. Koch BL. Cystic malformations of the neck in children. Pediatr Radiol 2005; 35(5): 463-477.

18. Shahin A, Burroughs FH, Kirby JP. Thyroglossal duct cyst: a cytopathologic study of 26 cases. Diagn Cytopathol 2005; 33(6): 365-369.

19. Foley DS, Fallat ME. Thyroglossal duct and other congenital midline cervical anomalies. Semin Pediatr Surg 2006; 15(2): 70-75.

20. Maddalozzo J, Venkatesan TK, Gupta P. Complications associated with the Sistrunk procedure. Laryngoscope 2001; 111(1): 119-123.

21. Enepekides DJ. Management of congenital anomalies of the neck. Facial Plast Surg Clin North Am 2001; 9(1): 131-145.

22. Mohan PS, Chokshi RA, Moser RL. Thyroglossal duct cysts: a consideration in adults. Am Surg 2005; 71(6): 508-511.

23. Patel NN, Hartley BE, Howard DJ. Management of thyroglossal tract disease after failed Sistrunk's procedure. J Laryngol Otol 2003; 117(9): 710-712.

24. Erikci V, Hoşgör M. A rare complication of the Sistrunk's procedure in thyroglossal duct remnant: tracheal injury. Annals Pediatr Surg 2014; 10: 130-132

25. El Bakkouri W, Racy E, Vereecke A. Squamous cell carcinoma in a thyroglossal duct cyst. Ann Otolaryngol Chir Cervicofac 2004; 121(5): 303- 305.

26. Waldhausen JH. Branchial cleft and arch anomalies in children. Semin Pediatr Surg 2006; 15(2): 64-69.

27. Albers GD. Branchial anomalies. JAMA 1963; 183: 399-409.

28. Torsiglieri AJ, Tom LW, Ross AJ. Pediatric neck masses: guidelines for evaluation. Int J Pediatr Otorhinolaryngol 1988; 16(3): 199-210.

29. Thomaidis V, Seretis K, Tamiolakis D. Branchial cysts. A report of 4 cases. Acta Dermatovenerol Alp Panonica Adriat 2006; 15(2): 85-89. 
30. Guldfred LA, Philipsen BB, Siim CJ. Branchial cleft anomalies: accuracy of pre-operative diagnosis, clinical presentation and management. J Laryngol Otol 2012; 126(6): 598-604.

31. Maddalozzo J, Rastatter JC, Dreyfuss HF. The second branchial cleft fistula. Int J Pediatr Otorhinolaryngol 2012; 76(7): 10421045.

32. Goff JC, Allred C, Glade RS. Current management of congenital branchial cleft cysts, sinuses, and fistulae. Curr Opin Otolaryngol Head Neck Surg 2012; 20(6): 533-539.

33. Roback SA, Telander RL. Thyroglossal duct cysts and branchial cleft anomalies. Semin Pediatr Surg 1994; 3(3): 142146.

34. O'Mara W, Amedee RG. Anomalies of the branchial apparatus. J La State Med Soc 1998; 150(12): 570-573.

35. Olusesi AD. Combined approach branchial sinusectomy: a new technique for excision of second branchial cleft sinus. J Laryngol Otol 2009; 123(10): 1166-1168.
36. Lagay EC. Complications in head and neck surgery. Seminars Ped Surg 2016; 25: 338-46.

37. Maddolozo J, Rastatter JC, Dreyfuss HF, Jaffar R, Bhushan B. The second branchial cleft fistula. Int $J$ Pediatr Otorhinolaryngol 2012; 76(7): 1042-1045.

38. Mou JW, Chan KW, Wong YS, Houben CH, Tam YH, Lee KH. Recurrent deep neck abcess and piriform sinus tract: a 15-year review on the diagnosis and management. J Pediatr Surg 2014; 49(8): 1264-7.

39. Keogh IJ, Khoo SG, Waheed K. Complete branchial cleft fistula: diagnosis and surgical management. Rev Laryngol Otol Rhinol (Bord) 2007; 128(1-2): 73-76.

40. Quintanilla DL, Penn EB. Congenital neck masses. Clin Perinatol 2018; 45(4): 769-85.

41. Goins MR, Beasley MS. Pediatric neck masses. Oral Maxillofacial Surg Clin North Am 2012;24:457-68.
This work is licensed under Creative Commons Attribution 4.0 License
To Submit Your Article Click Here: Submit Manuscript

DOI: $10.31579 / 2690-1919 / 063$
Ready to submit your research? Choose Auctores and benefit from:

* fast, convenient online submission

* rigorous peer review by experienced research in your field

* rapid publication on acceptance

* authors retain copyrights

* unique DOI for all articles

* immediate, unrestricted online access

At Auctores, research is always in progress.

Learn more www.auctoresonline.org/journals/journal-of-clinical-researchand-reports 